\title{
Prostate cancer in firefighting and police work: a systematic review and meta- analysis of epidemiologic studies
}

\author{
Jeavana Sritharan ${ }^{1,2^{*}}$ (D), Manisha Pahwa' ${ }^{1}$ Paul A. Demers ${ }^{1,2,3,4^{*}}$, Shelley A. Harris ${ }^{1,4,5}$, Donald C. Cole ${ }^{4}$
} and Marie-Elise Parent ${ }^{6}$

\begin{abstract}
Objectives: We conducted a systematic review and meta-analysis to evaluate potential associations between firefighting and police occupations, and prostate cancer incidence and mortality.

Methods: Original epidemiological studies published from 1980 to 2017 were identified through PubMed and Web of Science. Studies were included if they contained specific job titles for ever/never firefighting and police work and associated prostate cancer risk estimates with $95 \%$ confidence intervals $(\mathrm{Cl})$. Study quality was assessed using a 20-point checklist. Prostate cancer meta-risk estimates (mRE) and corresponding 95\% Cls were calculated for firefighting and police work separately and by various study characteristics using random effects models. Between-study heterogeneity was evaluated using the $I^{2}$ score. Publication bias was assessed using Begg's and Egger's tests.

Results: A total of 26 firefighter and 12 police studies were included in the meta-analysis, with quality assessment scores ranging from 7 to 19 points. For firefighter studies, the prostate cancer incidence mRE was $1.17(95 \% \mathrm{Cl}=1.08-1$. $\left.28, I^{2}=72 \%\right)$ and the mortality mRE was $1.12\left(95 \% \mathrm{Cl}=0.92-1.36, I^{2}=50 \%\right)$. The mRE for police incidence studies was 1 . $14\left(95 \% \mathrm{Cl}=1.02-1.28 ;\left.\right|^{2}=33 \%\right)$; for mortality studies, the mRE was $1.08\left(95 \% \mathrm{Cl}=0.80-1.45 ; I^{2}=0 \%\right)$. By study design, mREs for both firefighter and police studies were similar to estimates of incidence and mortality.

Conclusion: Small excess risks of prostate cancer were observed from firefighter studies with moderate to substantial heterogeneity and a relatively small number of police studies, respectively. There is a need for further studies to examine police occupations and to assess unique and shared exposures in firefighting and police work.
\end{abstract}

Keywords: Firefighters, Police, Occupation, Prostate cancer risk, Incidence, Mortality, Meta-analysis, Systematic review, Epidemiology

\section{Background}

Prostate cancer is one of the most commonly diagnosed cancers in men worldwide but its etiology remains poorly understood [1-5]. The only established risk factors for prostate cancer are older age, positive family history of prostate cancer, and African-American ethnicity $[1,2,4,5]$. There is some evidence linking prostate cancer to differences in socioeconomic status, increased height, increased

\footnotetext{
* Correspondence: jeavana.sritharan@occupationalcancer.ca; paul.demers@cancercare.on.ca

'Occupational Cancer Research Centre, Cancer Care Ontario, 525 University

Avenue, Toronto, ON M5G 2L3, Canada

Full list of author information is available at the end of the article
}

obesity, reduced physical activity, and active smoking and alcohol use [3,5-10]. There is growing evidence that occupation may be a risk factor, and previous studies have shown increased risks associated with employment in agriculture/farming, management and administration, rubber production, metal work, and transportation [11-13]. Some studies have also suggested associations between prostate cancer risk and employment in protective services occupations [11, 12, 15-17].

Protective services occupations include firefighting, police, military, and other groups (eg. security guards). Previous epidemiological studies have demonstrated consistent associations between firefighting and different 
types of cancer, with some evidence for prostate cancer [14]. In 2007, the International Agency for Research on Cancer (IARC) classified firefighting as "possibly" carcinogenic to humans (IARC Group 2B) [16]. IARC's evaluation was based on evidence from 42 epidemiological studies, including two previous meta-analyses on firefighting and cancer [14, 18]. Based on studies published at the time, IARC evaluated multiple cancer sites and identified statistically significant increased risks of prostate cancer, testicular cancer, and non-Hodgkin lymphoma [16]. Since the IARC evaluation, 11 new studies have been published that included assessments of prostate cancer risk in firefighters. Relatively less is known about prostate cancer risk in police occupations, as this group is often understudied and findings have been inconsistent $[11,12,15,19,20]$.

Only one meta-analysis, published over a decade ago, focused on firefighting and cancer risks that included prostate cancer [14]. This study found a significant association with prostate cancer incidence (summary risk estimate: 1.28 , 95\% CI: $1.15-1.43$ ) based on evidence from 6 cohort studies [14]. Recently, a narrative review examined cancer risk in police work. Eight studies reported on prostate cancer risk in police work, with mixed findings [15]. The objective of the present systematic review and meta-analysis was to evaluate the quality of the epidemiological evidence on firefighting and police employment in association with prostate cancer incidence and mortality, and to conduct a quantitative synthesis. Based on the availability of epidemiologic literature, this meta-analysis focused on firefighting and police work, and not protective services as a whole.

\section{Material and methods}

\section{Search strategy}

A search was conducted on PubMed and Web of Science to identify epidemiological studies published between January 1980 and December 2017 in English or French about employment in firefighting and police occupations, and risk of prostate cancer. Various combinations of $\mathrm{MeSH}$ terms were used to search for studies that included firefighter and police occupations (firefighting OR firefighter OR fire fighter OR fire OR police OR police officer OR policeman OR policemen) and that reported on associations with prostate cancer risk (prostate OR prostate neoplasm OR neoplasm OR cancer). Cited references in individual papers and review papers that resulted from the search were used to identify any additional studies.

\section{Inclusion criteria}

To be included in the meta-analysis, articles must have reported results for original case-control or cohort studies that contained specific job titles related to ever/never firefighting and police work and that examined associated prostate cancer incidence and/or mortality using any type of relative risk estimator (hazard ratio (HR), odds ratio (OR), relative risk (RR), standardized mortality ratio (SMR), or standardized incidence ratio (SIR)) with corresponding 95\% confidence intervals. Reviews, meta-analyses, editorials, and experimental studies were excluded. For any articles with overlapping study populations, only the most recently published study with prostate cancer incidence and/or mortality results was included. Furthermore, studies were excluded if reported risk estimates were only based on internal comparisons between different occupational groups rather than based on comparisons to the general population. Titles and abstracts were initially screened for eligibility, and for those eligible, full-text articles were reviewed.

\section{Data extraction}

Information on author(s), date of publication, title, country of study, study design, number of cases/deaths and controls/non-cases, data collection method, effect sizes and 95\% CIs for prostate cancer, and covariates was extracted from and tabulated for each study included in the meta-analysis. Effect sizes and 95\% $\mathrm{Cls}$ recorded from included studies were for ever vs. never firefighter or police employment in models that were adjusted for the maximum number of potentially confounding variables.

\section{Quality assessment}

The quality of each study included in the meta-analysis was independently assessed by two authors (JS and MP) using a modified quality assessment checklist by Downs and Black [21]. Checklist items that were irrelevant to observational studies were omitted, resulting in a maximum of 20 achievable points for reporting (9 points), external validity ( 2 points), internal validity (bias and confounding) (8 points), and power (1 point) [21]. Any disagreement of ratings was discussed and a consensus was arrived at mutually or by consulting a third author, if earlier consensus could not be reached.

\section{Statistical analysis}

Reported ORs, HRs, RRs, SIRs, and SMRs were considered as RRs in meta-analyses and used in forest plots. A random effects model was used to calculate meta-risk estimates (mREs) in all meta-analyses due to potential variance in effect sizes between the included studies. mREs were calculated separately for firefighting and police occupations and prostate cancer risk. mREs were calculated for subgroups based on the following characteristics: incidence versus mortality, study design (i.e. cohort versus case-control, and administrative linkage-based studies, 
defined as large studies that used multiple linked administrative databases, e.g. census data and tumour registries.

For each mRE, heterogeneity was evaluated using the $\mathrm{I}^{2}$ statistic. The $\mathrm{I}^{2}$ statistic is a percentage that describes the variation between studies that is not due to chance [22]. Two-sided $p$-values for the I2 statistic were reported. Ninety-five percent confidence intervals for the I2 statistic were calculated to address small numbers of included studies $(N<5)$ in some subgroup metaanalyses. In addition, the Galbraith plot was used to visualize if individual studies fell within or outside of the 95\% confidence region. Studies outside of the 95\% confidence region can contribute to high heterogeneity. These studies were removed in sensitivity analyses to evaluate the impact of decreased heterogeneity on mREs [23].

Begg's test and Egger's test were used to assess publication bias. Begg's test uses the correlation between ranks of effect sizes and variances, whereas Egger's test uses a funnel plot to plot the effect estimates against sample size [24, 25]. All statistical analyses were performed using STATA version 14.2 (StataCorp LLC, College Station, USA).

\section{Results}

The literature search resulted in 366 unique studies published in English or French. Based on the screening of titles and abstracts, 318 (87\%) were excluded due to nonobservational/non-human studies, missing job titles, missing effect estimates for prostate cancer, duplicate studies, or irrelevancy to the objective of this meta-analysis. Of the remaining 48 studies that were obtained in full text, 17 were excluded because they did not include reports of relative risks for prostate cancer with 95\% CIs, had overlapping study populations, or were studies of military workers. As a result, 31 unique studies were included (Fig. 1).
Of these, 24 were cohort and seven were case-control studies. Nineteen studies only included investigations of firefighters (Table 1) and five focused on police workers (Table 2); seven contained investigations of both firefighters and police workers (Table 3 ). In all studies that included firefighters $(N=26)$, there were 5712 incident cases of prostate cancer and 428 deaths from prostate cancer. In all studies that included police workers $(N=12)$, there were 1510 incident cases and 49 deaths. The characteristics of each included study are summarized in Tables 1 (firefighters), 2 (police workers), and 3 (both). Covariates included in the risk estimates selected from each of the seven case-control studies are shown in Additional file 1: Table S1.

Of all the firefighter studies, 2 pairs of studies (Ma et al., 2005 \& Ma et al., 2006; Demers et al., 1992 \& Demers et al., 1994) [26-29] examined the same respective populations but reported on different prostate cancer outcomes (incidence and mortality). In the meta-analyses of prostate cancer incidence and mortality in firefighters, respective results from both pairs of studies were retained and used. Two studies [30, 31] published results for both prostate cancer incidence and mortality, and each estimate was used [31, 32]. For the police studies, [28, 29] reported on the same populations with different outcomes of incidence and mortality, and each estimate was used. Each incidence and mortality outcome was used only in their respective categories and not included together for any meta-risk estimates.

\section{Quality assessment}

The overall quality assessment of all 31 included studies ranged from 5 to 19 points (Table 4). Scores were similar for firefighter, police, and firefighter and police studies across the different quality assessment categories. The mean score for reporting was 6 out of 9 , based on clear

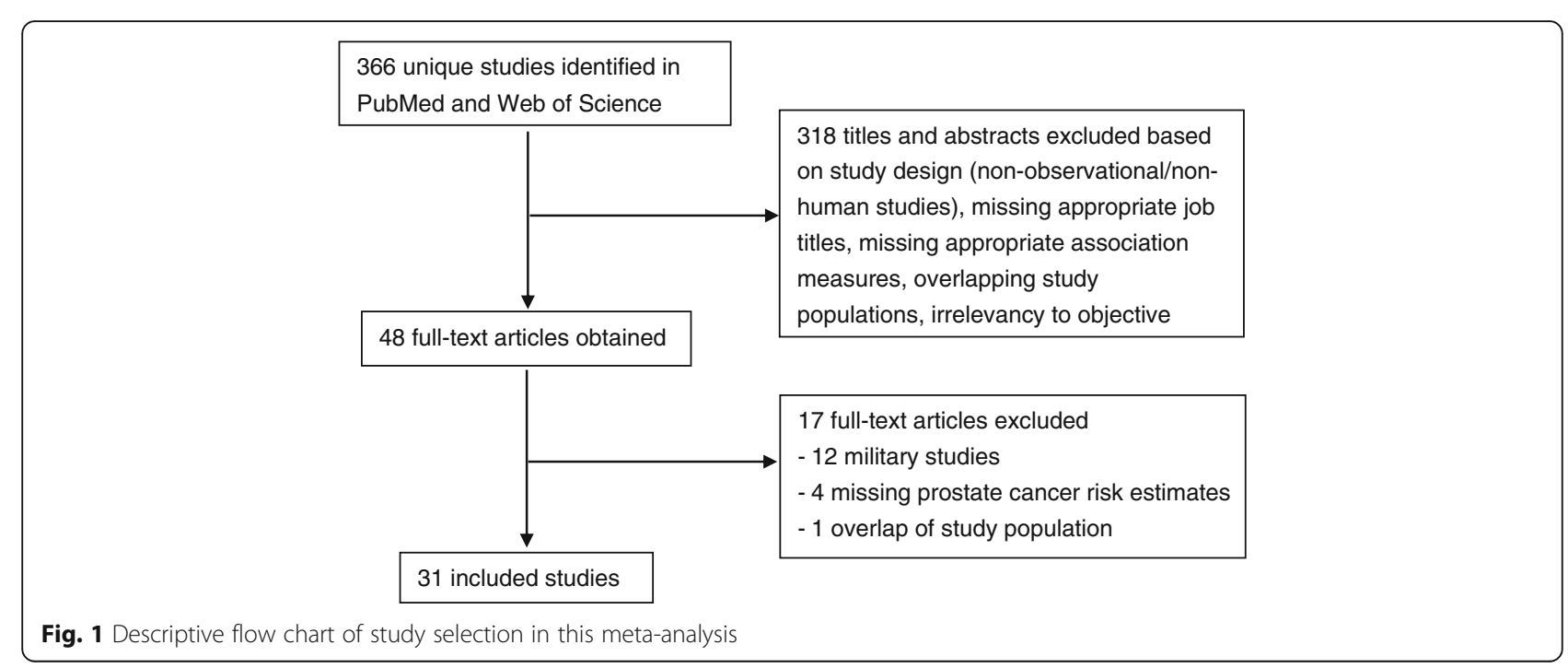


Table 1 Characteristics of included studies on firefighting and prostate cancer risk $(N=19)$

\begin{tabular}{|c|c|c|c|c|c|c|c|}
\hline $\begin{array}{l}\text { Author/ } \\
\text { Year }\end{array}$ & Location of Study & $\begin{array}{l}\text { Study } \\
\text { Design }\end{array}$ & $\begin{array}{l}\text { Incidence or } \\
\text { Mortality }\end{array}$ & $\begin{array}{l}\text { Follow- } \\
\text { up period }\end{array}$ & $\begin{array}{l}\text { Number of } \\
\text { Cases/ } \\
\text { Deaths }\end{array}$ & $\begin{array}{l}\text { Cohort Size/Total } \\
\text { Number of } \\
\text { Cases }^{a}\end{array}$ & $\begin{array}{l}\text { Prostate Cancer Risk Estimates } \\
\text { for Ever versus Never } \\
\text { Employment }^{\mathrm{b}}\end{array}$ \\
\hline $\begin{array}{l}\text { Glass et al. } \\
2016 \text { [63] }\end{array}$ & Australia & Cohort & Incidence & $\begin{array}{l}1980- \\
2011\end{array}$ & 478 & 30,057 & SIR 1.31, 95\% CI 1.19-1.43 \\
\hline $\begin{array}{l}\text { Brice et al. } \\
2015 \text { [64] }\end{array}$ & France & Cohort & Mortality & $\begin{array}{l}1979- \\
2008\end{array}$ & 17 & 10,829 & SMR $0.54,95 \%$ Cl $0.31-0.86$ \\
\hline $\begin{array}{l}\text { Daniels } \\
\text { et al. } 2014 \\
\text { [32] }\end{array}$ & USA & Cohort & $\begin{array}{l}\text { Incidence; } \\
\text { Mortality }\end{array}$ & $\begin{array}{l}1950- \\
2009\end{array}$ & $\begin{array}{l}1261 \text { cases } \\
282 \text { deaths }\end{array}$ & $\begin{array}{l}29,993 \\
29,993\end{array}$ & $\begin{array}{l}\text { SIR 1.03, 95\% Cl 0.98-1.09; } \\
\text { SMR 1.09, 95\% CI 0.96-1.22 }\end{array}$ \\
\hline $\begin{array}{l}\text { Pukkala } \\
\text { et al. } 2014 \\
{[17]}\end{array}$ & $\begin{array}{l}\text { Denmark, Finland, } \\
\text { Iceland, Norway } \\
\text { and Sweden }\end{array}$ & $\begin{array}{l}\text { Cohort } \\
\text { (linkage) }\end{array}$ & Incidence & $\begin{array}{l}1961- \\
2005\end{array}$ & 660 & 16,422 & SIR $1.13,95 \%$ CI 1.03-1.22 \\
\hline $\begin{array}{l}\text { Ahn et al. } \\
2012 \text { [65] }\end{array}$ & Korea & Cohort & Incidence & $\begin{array}{l}1996- \\
2007\end{array}$ & 9 & 33,416 & SIR 1.32, 95\% CI 0.60-2.51 \\
\hline $\begin{array}{l}\text { Ma et al. } \\
2006[27]\end{array}$ & USA & Cohort & Incidence & $\begin{array}{l}1981- \\
1999\end{array}$ & 209 & 34,796 & SIR $1.10,95 \%$ CI 0.95-1.42 \\
\hline $\begin{array}{l}\text { Ma et al. } \\
2005 \text { [26] }\end{array}$ & USA & Cohort & Mortality & $\begin{array}{l}1972- \\
1999\end{array}$ & 21 & 34,796 & SMR $1.08,95 \%$ Cl 0.67-1.65 \\
\hline $\begin{array}{l}\text { Baris et al. } \\
2001 \text { [66] }\end{array}$ & USA, USA & Cohort & Mortality & $\begin{array}{l}1925- \\
1986\end{array}$ & 31 & 7,789 & SMR 0.96, 95\% Cl 0.68-1.37 \\
\hline $\begin{array}{l}\text { Bates et al. } \\
2001[67]\end{array}$ & New Zealand & Cohort & Incidence & $\begin{array}{l}1977- \\
1995\end{array}$ & 11 & 4,221 & SIR $1.08,95 \%$ CI 0.50-1.90 \\
\hline $\begin{array}{l}\text { Tornling } \\
\text { et al. } 1994 \\
\text { [31] }\end{array}$ & Sweden & Cohort & $\begin{array}{l}\text { Incidence; } \\
\text { Mortality }\end{array}$ & $\begin{array}{l}1951- \\
1986\end{array}$ & $\begin{array}{l}28 \text { cases } \\
14 \text { deaths }\end{array}$ & $\begin{array}{l}1,116 \\
1,091\end{array}$ & $\begin{array}{l}\text { SMR 114, 95\% Cl 76-165; } \\
\text { SMR 121, 95\% Cl 66-202 }\end{array}$ \\
\hline $\begin{array}{l}\text { Aronson } \\
\text { et al. } 1994 \\
\text { [68] }\end{array}$ & Canada & Cohort & Mortality & $\begin{array}{l}1950- \\
1989\end{array}$ & 16 & 5,373 & SMR 132, 95\% Cl 76-215 \\
\hline $\begin{array}{l}\text { Giles et al. } \\
1993 \text { [69] }\end{array}$ & Australia & Cohort & Incidence & $\begin{array}{l}1980- \\
1989\end{array}$ & 5 & 2,865 & SIR 2.09, 95\% CI 0.67-4.88 \\
\hline $\begin{array}{l}\text { Guidotti } \\
1993[70]\end{array}$ & Canada & Cohort & Mortality & $\begin{array}{l}1927- \\
1987\end{array}$ & 8 & 3,328 & SMR 146.1, 95\% Cl 63.1-287.9 \\
\hline $\begin{array}{l}\text { Beaumont } \\
\text { et al. } 1991 \\
\text { [33] }\end{array}$ & USA & Cohort & Incidence & $\begin{array}{l}1940- \\
1982\end{array}$ & 8 & 3,066 & RR $0.38,95 \%$ Cl 0.16-0.75 \\
\hline $\begin{array}{l}\text { Grimes } \\
\text { et al. } 1991 \\
\text { [71] }\end{array}$ & USA & Cohort & Mortality & $\begin{array}{l}1969- \\
1988\end{array}$ & 4 & 205 & PRR 2.6, 95\% Cl 1.4-5.0 \\
\hline $\begin{array}{l}\text { Vena \& } \\
\text { Friedler } \\
1987 \text { [72] }\end{array}$ & USA & Cohort & Mortality & $\begin{array}{l}1950- \\
1979\end{array}$ & 5 & 470 & SMR 0.71, 95\% Cl 0.23-1.65 \\
\hline $\begin{array}{l}\text { Tsai et al. } \\
2015 \text { [73] }\end{array}$ & USA & $\begin{array}{l}\text { Case- } \\
\text { control } \\
\text { (linkage) }\end{array}$ & Incidence & $\begin{array}{l}1988- \\
2007\end{array}$ & 1397 & 3,996 & OR $1.45,95 \%$ Cl 1.25-1.69 \\
\hline $\begin{array}{l}\text { Kang et al., } \\
2008 \text { [74] }\end{array}$ & USA & $\begin{array}{l}\text { Case- } \\
\text { control } \\
\text { (linkage) }\end{array}$ & Incidence & $\begin{array}{l}1986- \\
2003\end{array}$ & 577 & 285,964 & SMOR 1.05, 95\% Cl 0.88-1.24 \\
\hline $\begin{array}{l}\text { Krstev et al. } \\
1998 \text { [75] }\end{array}$ & USA & $\begin{array}{l}\text { Case- } \\
\text { control }\end{array}$ & Incidence & $\begin{array}{l}1986- \\
1989\end{array}$ & 12 & 981 & OR 3.34, 95\% Cl 1.13-9.91 \\
\hline
\end{tabular}

\footnotetext{
${ }^{a}$ cohort size represents the total sample size in only cohort studies, and the total number of cases is only applicable to case-control studies

${ }^{\mathrm{b}} \mathrm{HR}$ - hazard ratio, SIR - standardized incidence ratio, SMR - standardized mortality/morbidity ratio, RR - relative risk, PRR - proportionate risk ratio, OR - odds ratio, NR - not reported
}

and detailed reporting of aims/hypotheses, outcomes measures, participant information, confounder information, and loss to follow-up. Studies were generally found to be externally valid, and there was minimal bias.
Studies of firefighters had higher scores for confounding factors than studies of police workers. Only one study reported a power calculation making it difficult to evaluate this category. 
Table 2 Characteristics of included studies on police work and prostate cancer risk $(N=5)$

\begin{tabular}{|c|c|c|c|c|c|c|c|}
\hline Author/Year & $\begin{array}{l}\text { Location of } \\
\text { Study }\end{array}$ & $\begin{array}{l}\text { Study } \\
\text { Design }\end{array}$ & $\begin{array}{l}\text { Incidence or } \\
\text { Mortality }\end{array}$ & $\begin{array}{l}\text { Follow-up } \\
\text { Period }\end{array}$ & $\begin{array}{l}\text { Number of } \\
\text { Cases/Deaths }\end{array}$ & $\begin{array}{l}\text { Cohort Size/Total } \\
\text { Number of Cases }^{a}\end{array}$ & $\begin{array}{l}\text { Prostate Cancer Risk Estimates for Ever } \\
\text { versus Never Employment }{ }^{b}\end{array}$ \\
\hline $\begin{array}{l}\text { Vena et al. } 2014 \\
\text { [19] }\end{array}$ & USA & Cohort & Mortality & $\begin{array}{l}1980- \\
2005\end{array}$ & 31 & 3,424 & SMR 1.18, 95\% Cl 0.80-1.67 \\
\hline $\begin{array}{l}\text { Gu et al. } 2011 \\
{[76]}\end{array}$ & USA & Cohort & Incidence & $\begin{array}{l}1976- \\
2006\end{array}$ & 104 & 2,234 & SIR 0.88, 95\% CI 0.72-1.07 \\
\hline $\begin{array}{l}\text { Finkelstein } 1998 \\
\text { [20] }\end{array}$ & Canada & Cohort & Incidence & $\begin{array}{l}1964- \\
1995\end{array}$ & 85 & 22,197 & SIR 1.16, 95\% CI 0.93-1.43 \\
\hline $\begin{array}{l}\text { Forastiere et al. } 1994 \\
\text { [77] }\end{array}$ & Italy & Cohort & Mortality & $\begin{array}{l}1973- \\
1991\end{array}$ & 7 & 3,868 & SMR 0.77, 95\% Cl 0.31-1.50 \\
\hline $\begin{array}{l}\text { Bouchardy et al. } 2002 \\
\text { [78] }\end{array}$ & Switzerland & $\begin{array}{l}\text { Case- } \\
\text { control }\end{array}$ & Incidence & $\begin{array}{l}1980- \\
1993\end{array}$ & 129 & 9,126 & OR $1.20,95 \%$ Cl 1.00-1.50 \\
\hline
\end{tabular}

${ }^{a}$ cohort size represents the total sample size in only cohort studies, and the total number of cases is only applicable to case-control studies

${ }^{b} \mathrm{HR}$ - hazard ratio, SIR - standardized incidence ratio, SMR - standardized mortality/morbidity ratio, RR - relative risk, OR - odds ratio

\section{Firefighter and prostate cancer meta-analyses}

There were significantly elevated prostate cancer risks for firefighting occupations for incidence outcomes, cohort studies, and administrative linkage-based studies. For incidence studies, the mRE was 1.17 (95\% CI: 1.08-1.28; $\mathrm{I}^{2}=72 \%, 95 \%$ CI: 55-82\%, $p$-value $<0.001 ; 19$ studies) (Fig. 2); for mortality studies, it was 1.12 (95\% CI: 0.921.36; $\mathrm{I}^{2}=50 \%, 95 \%$ CI: $0-76 \%$, p-value $=0.04 ; 10$ studies) (Fig. 3). In cohort studies, the prostate cancer mRE was 1.14 (95\% CI: $1.03-1.26$; $\mathrm{I}^{2}=67 \%$, 95\% CI: $46-80 \%, p$-value $<0.001 ; 18$ studies) (Additional file 2: Figure S1). The metaanalysis of case-control studies resulted in an mRE of 1.27 (95\% CI: $0.95-1.69 ; \mathrm{I}^{2}=78 \%, 95 \%$ CI: $53-90 \%, p$-value $<0.001 ; 6$ studies) (Additional file 3: Figure S2). The mRE for census or administrative linkage-based studies was 1.19 (95\% CI: $1.06-1.34 ; \mathrm{I}^{2}=61 \%, 95 \%$ CI: 0-85\%, $p$-value $=0.04$; 5 studies) (Additional file 4: Figure S3).
Police work and prostate cancer meta-analyses

There were significantly elevated prostate cancer risks for police occupations by incidence outcomes and in casecontrol studies. The $\mathrm{mRE}$ for prostate cancer incidence studies was 1.14 (95\% CI: $1.02-1.28$; $\mathrm{I}^{2}=33 \%$, 95\% CI: 0 $74 \%, p$-value $=0.16 ; 9$ studies) (Fig. 4$)$ while the $\mathrm{mRE}$ for prostate cancer mortality studies was 1.08 (95\% CI: 0.80 $1.45 ; \mathrm{I}^{2}=0 \%, 95 \%$ CI: $0 \%-90 \%, p$-value $=0.62 ; 3$ studies $)$ (Fig. 5). The mRE for case-control studies was higher compared to the mRE for cohort studies (case-control studies: $\mathrm{mRE}=1.22,95 \% \mathrm{CI}: 1.03-1.44 ; \mathrm{I}^{2}=0 \%(95 \% \mathrm{CI}$ $0 \%-85 \%$, p-value $=0.42 ; 4$ studies) (Additional file 5 : Figure S4) versus cohort studies: $\mathrm{mRE}=1.10,95 \% \mathrm{CI}$ : $0.96-1.26 ; \mathrm{I}^{2}=37 \%, 95 \%$ CI: 0-79\%, p-value $=0.15 ; 7 \mathrm{stu}-$ dies) (Additional file 6: Figure S5). There were no administrative linkage-based studies of police workers and prostate cancer risk.

Table 3 Characteristics of included studies on both firefighting and police work and prostate cancer risk $(N=7)$

\begin{tabular}{|c|c|c|c|c|c|c|c|}
\hline Author/Year & $\begin{array}{l}\text { Location of } \\
\text { Study }\end{array}$ & $\begin{array}{l}\text { Study } \\
\text { Design }\end{array}$ & $\begin{array}{l}\text { Incidence or } \\
\text { Mortality }\end{array}$ & $\begin{array}{l}\text { Follow-up } \\
\text { Period }\end{array}$ & $\begin{array}{l}\text { Number of } \\
\text { Cases/Deaths }\end{array}$ & $\begin{array}{l}\text { Cohort Size/Total } \\
\text { Number of Cases }^{a}\end{array}$ & $\begin{array}{l}\text { Prostate Cancer Risk Estimates for } \\
\text { Ever versus Never Employment }{ }^{b}\end{array}$ \\
\hline Sritharan et al, 2017b* & Canada & $\begin{array}{l}\text { Cohort } \\
\text { (linkage) }\end{array}$ & Incidence & $\begin{array}{l}1991- \\
2011\end{array}$ & $\begin{array}{l}165 \text { firefighters; } \\
325 \text { police }\end{array}$ & $\begin{array}{l}1,100,000 \\
1,100,000\end{array}$ & $\begin{array}{l}\text { HR 1.17, 95\% Cl 1.01-1.36; } \\
\text { HR 1.22, 95\% Cl 1.09-1.36 }\end{array}$ \\
\hline $\begin{array}{l}\text { Zeegers et al. } \\
2004 \text { [11] }\end{array}$ & Netherlands & $\begin{array}{l}\text { Cohort } \\
\text { (linkage) }\end{array}$ & Incidence & $\begin{array}{l}1986- \\
1993\end{array}$ & $\begin{array}{l}709 \text { firefighters; } \\
693 \text { police }\end{array}$ & $\begin{array}{l}58,279 \\
58,279\end{array}$ & $\begin{array}{l}\text { RR 0.59, 95\% Cl 0.05-6.33; } \\
\text { RR 1.62,95\% Cl 0.62-4.27 }\end{array}$ \\
\hline $\begin{array}{l}\text { Demers et al. } \\
1994 \text { [28] }\end{array}$ & USA & Cohort & Incidence & $\begin{array}{l}1974- \\
1989\end{array}$ & $\begin{array}{l}66 \text { firefighters; } \\
28 \text { police }\end{array}$ & $\begin{array}{l}2,447 \\
1,878\end{array}$ & $\begin{array}{l}\text { SIR 1.40, 95\% Cl 1.10-1.70; } \\
\text { IDR 1.10, 95\% CI 0.70-1.80 }\end{array}$ \\
\hline $\begin{array}{l}\text { Demers et al. } \\
1992 \text { [29] }\end{array}$ & USA & Cohort & Mortality & $\begin{array}{l}1945- \\
1989\end{array}$ & $\begin{array}{l}30 \text { firefighters; } \\
11 \text { police }\end{array}$ & $\begin{array}{l}4,546 \\
3,676\end{array}$ & $\begin{array}{l}\text { SMR 1.34, 95\% Cl 0.90-1.91; } \\
\text { SMR 1.02, 95\% Cl 0.51-1.82 }\end{array}$ \\
\hline $\begin{array}{l}\text { Sritharan et al. } \\
\text { 2017a [79] }\end{array}$ & Canada & $\begin{array}{l}\text { Case- } \\
\text { control }\end{array}$ & Incidence & $\begin{array}{l}1995- \\
1998\end{array}$ & $\begin{array}{l}38 \text { firefighters; } \\
35 \text { police }\end{array}$ & $\begin{array}{l}1,737 \\
1,737\end{array}$ & $\begin{array}{l}\text { OR 1.67, 95\% Cl 0.94-2.95; } \\
\text { OR 1.15, 95\% Cl 0.66-1.99 }\end{array}$ \\
\hline $\begin{array}{l}\text { Sritharan et al. } \\
2016 \text { [80] }\end{array}$ & Canada & $\begin{array}{l}\text { Case- } \\
\text { control }\end{array}$ & Incidence & $\begin{array}{l}1994- \\
1997\end{array}$ & $\begin{array}{l}53 \text { firefighters; } \\
12 \text { police }\end{array}$ & $\begin{array}{l}760 \\
760\end{array}$ & $\begin{array}{l}\text { OR } 0.73,95 \% \text { Cl } 0.53-1.01 \\
\text { OR } 0.82,95 \% \text { Cl } 0.41-1.63\end{array}$ \\
\hline $\begin{array}{l}\text { Sauve et al. } \\
2016 \text { [12] }\end{array}$ & Canada & $\begin{array}{l}\text { Case- } \\
\text { control }\end{array}$ & Incidence & $\begin{array}{l}2005- \\
2009\end{array}$ & $\begin{array}{l}26 \text { firefighters; } \\
45 \text { police }\end{array}$ & $\begin{array}{l}1,937 \\
1,937\end{array}$ & $\begin{array}{l}\text { OR 1.72, 95\% Cl 0.88-3.37; } \\
\text { OR 1.60, 95\% Cl 1.00-2.40 }\end{array}$ \\
\hline
\end{tabular}

${ }^{a}$ cohort size represents the total sample size in only cohort studies, and the total number of cases is only applicable to case-control studies

${ }^{b} \mathrm{HR}$ - hazard ratio, SIR - standardized incidence ratio, SMR - standardized mortality/morbidity ratio, RR - relative risk, IDR - incidence density ratio, OR - odds ratio *manuscript submitted and currently being revised for publication 
Table 4 Quality assessment of included firefighter and police studies

\begin{tabular}{|c|c|c|c|c|c|c|c|c|}
\hline \multirow[t]{2}{*}{ Quality Assessment Category } & \multirow[t]{2}{*}{$\begin{array}{l}\text { Maximum Attainable } \\
\text { Score }\end{array}$} & \multicolumn{2}{|c|}{$\begin{array}{l}\text { Studies on firefighters } \\
(n=19)\end{array}$} & \multicolumn{2}{|c|}{$\begin{array}{l}\text { Studies on police } \\
\text { workers }(n=5)\end{array}$} & \multicolumn{2}{|c|}{$\begin{array}{l}\text { Studies on both firefighters } \\
\text { and police workers }(n=7)\end{array}$} & \multirow{2}{*}{$\begin{array}{l}\text { All studies }(n=31) \\
\text { Mean }\end{array}$} \\
\hline & & Range & Mean & Range & Mean & Range & Mean & \\
\hline Reporting & 9 & $4-9$ & 6.0 & $1-8$ & 5.4 & $4-8$ & 6.1 & 5.9 \\
\hline External Validity & 2 & $1-2$ & 1.8 & $0-2$ & 1.6 & $1-2$ & 1.6 & 1.7 \\
\hline Internal Validity: Bias & 4 & $3-4$ & 3.8 & $3-4$ & 3.8 & 4 & 4 & 3.8 \\
\hline Internal Validity: Confounding & 4 & $2-4$ & 3.2 & $1-4$ & 2.8 & $3-4$ & 3.6 & 3.2 \\
\hline Power & 1 & 0 & 0 & 0 & 0 & $0-1$ & 0.1 & 0.0 \\
\hline Total & 20 & $10-19$ & 14.8 & $5-18$ & 13.6 & $12-18$ & 15.4 & 14.6 \\
\hline
\end{tabular}

\section{Between-study heterogeneity}

There was high heterogeneity (72\%) for the meta-analysis of all 19 firefighter incidence studies. As a sensitivity analysis, the Galbraith plot was used and one study [33], appeared outside of the $95 \%$ confidence region. Removal of this study resulted in a minimal change in heterogeneity (72 versus 69\%, respectively). For the meta-analysis of the 10 mortality studies, there was moderate heterogeneity (50\%). High heterogeneity was observed for the six casecontrol studies (78\%), 18 cohort studies (67\%) and the five administrative linkage-based studies (61\%). When plotting these subgroups using the Galbraith plot, no studies appeared outside of the $95 \%$ confidence region.

For police studies, heterogeneity ranged from none to moderate. Moderate heterogeneity was observed for the nine incidence studies (33\%) and seven cohort studies
(37\%), but no heterogeneity (0\%, 95\% CI: 0-90\%) was observed for the mortality (three studies) and case-control (four studies) subgroups. $\mathrm{I}^{2}$ values of $0 \%$ are biased and imprecise, likely because of the small number of studies in these subgroups $(n<5)$ [34]. Using the Galbraith plot, none of the police studies appeared outside of the $95 \%$ confidence region.

\section{Publication bias}

There was no evidence of publication bias according to Begg's test $(p=0.86)$ and Egger's test $(p=0.11)$ for the meta-analysis of all 19 firefighter incidence studies. No publication bias was evident for the 9 police incidence studies (Begg's test: $p=0.60$, Egger's test: $p=0.68$ ). There were also no statistically significant findings for

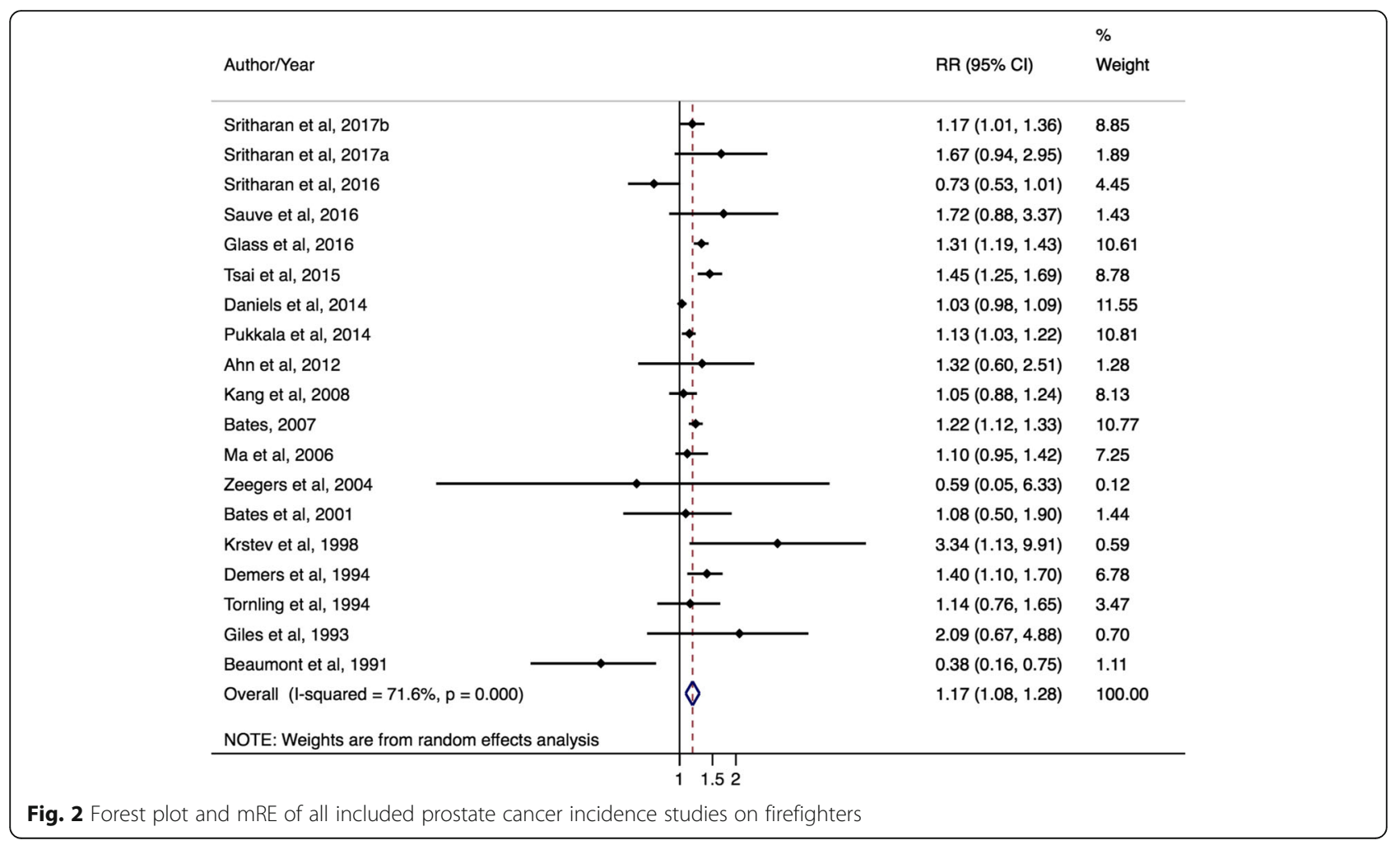




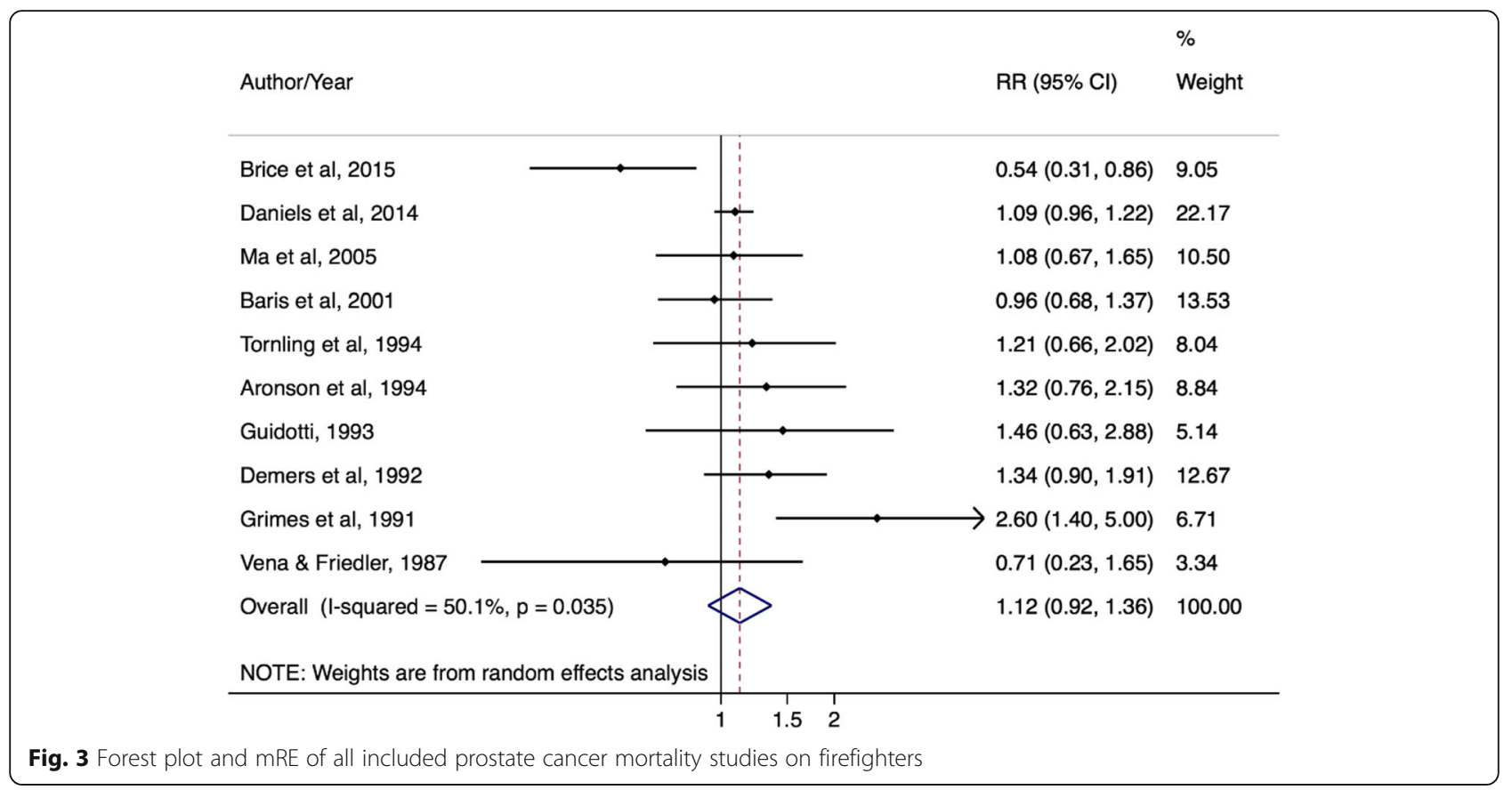

publication bias for mortality studies, case-control, cohort, and administrative linkage-based studies.

\section{Discussion}

In this meta-analysis of 31 epidemiological studies of protective services workers, nearly identical and small statistically significant excess risks of prostate cancer were found for ever working in firefighting and police work. Statistically significant and borderline prostate cancer mREs were found for firefighters in separate evaluations of incidence studies, cohort studies, and administrative linkage studies, as well as in each meta-analysis of police worker incidence studies and case-control studies. Most studies were of average quality, with opportunities for improvement in reporting and study power assessment. As expected, casecontrol studies compared to cohort studies generally had more information on variables that can act as potential confounders of the firefighter/police work and prostate cancer associations. All case-control studies reported prostate cancer risk estimates that were adjusted for age;

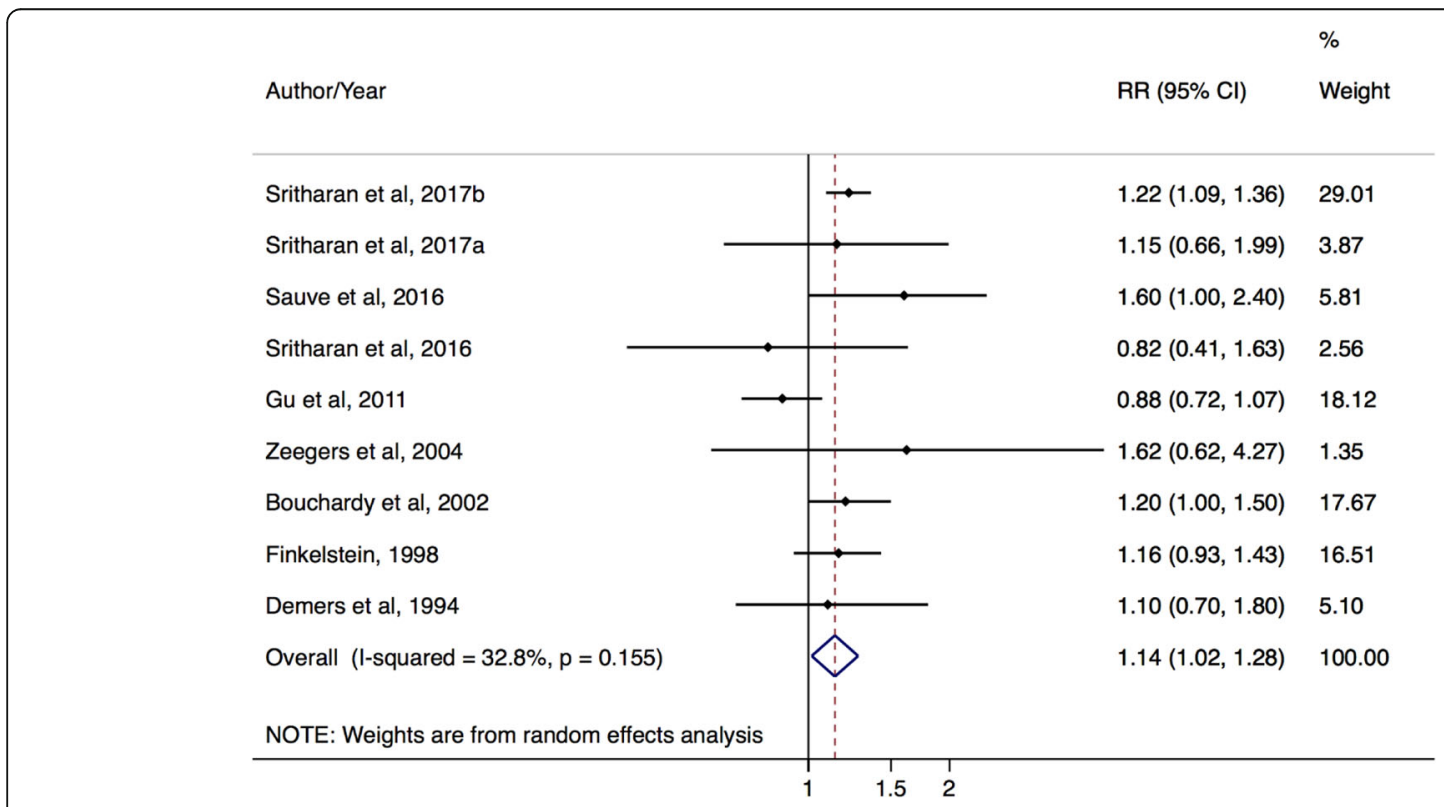

Fig. 4 Forest plot and mRE of all included prostate cancer incidence studies on police workers 


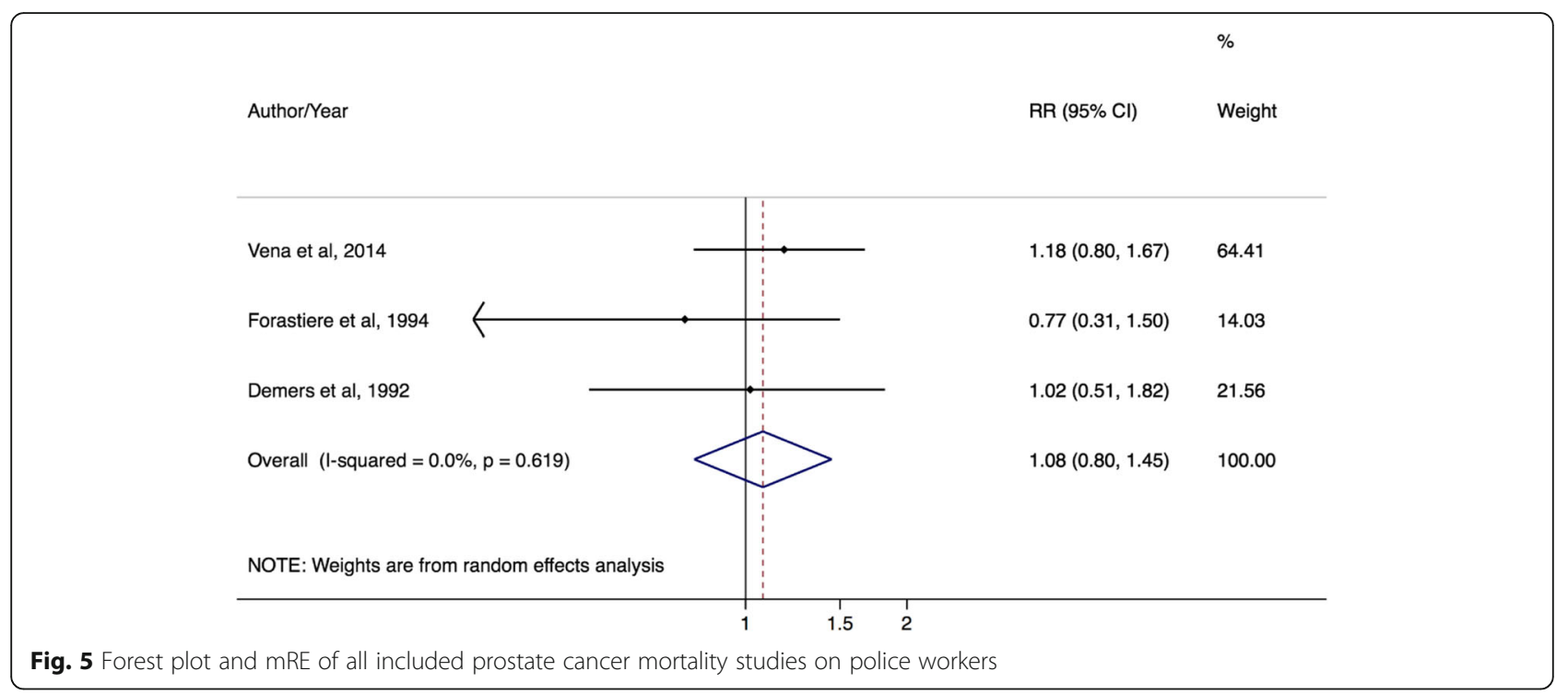

most were also adjusted for ethnicity. Fewer case-control studies adjusted risk estimates for family history of prostate cancer and potentially confounding variables such as socioeconomic status, physical activity, height, obesity, active smoking, and alcohol consumption. Overall, findings from this meta-analysis support positive associations found between prostate cancer risk and firefighting in the epidemiological literature, and indicate a potential relationship with police work as well.

There are a few hypotheses that may explain why employment in protective services occupations could be associated with increased prostate cancer risk. Firefighting and police jobs are inherently dangerous occupations that involve stressful, and, at times, life-threatening, situations with exposure to multiple hazards [14-16]. Psychological stressors can influence biological processes and lead to decreased immune function, increased proinflammatory cytokine secretion, and cancer progression [15]. Shift work, which is common in protective services work, was significantly associated with increased prostate cancer risk in a recent meta-analysis of eight casecontrol and cohort studies [35]. Firefighters are also exposed to toxins released by fire and smoke including benzene, 1,3-butadiene, formaldehyde and at times can be exposed to other compounds such as radiation, diesel exhaust, asbestos, metals (arsenic and cadmium), and PAHs $[14,16,27]$. The chemical reactions during combustion and the age and type of building or material on fire can contribute to exposure to these compounds [16]. Police work involves fewer chemical exposures compared to firefighting, although exposure to ionizing radiation from radar devices is a concern for overall cancer risk $[11,12]$. Firefighters and police workers may also be exposed to air pollution on the job, as ambient concentrations of ultrafine particles and $\mathrm{NO}_{2}$ have been previously linked to prostate cancer risk [36, 37]. Of the described chemical exposures, only $\mathrm{x}$ and gamma radiation, arsenic compounds, and cadmium compounds have been linked to prostate cancer by IARC based on limited evidence in non-occupational settings. However, IARC has classified benzene, ionizing radiation, diesel exhaust, asbestos, arsenic compounds, cadmium compounds, and air pollution as all Group 1 carcinogens, based on evidence for other cancer sites [38]. There is a need to further examine these chemical exposures in both firefighting and police work to understand if these exposures are involved in prostate cancer risk.

Evaluating potential associations between shift work and prostate cancer is an active area of ongoing research [39-41]. Shift work can disrupt the body's endogenous circadian rhythm (sleep-wake cycle) and contribute to increased susceptibility to acute and chronic diseases. However, the biological mechanisms that may be involved in prostate and other cancers have not been established [18, 42]. One hypothesis is that night shift work can lead to decreased melatonin, which can then lead to continuous testosterone production, influencing the growth and differentiation of prostate cancer cells [16]. In addition, decreased sunlight exposure in night shift workers reduces the production of vitamin $\mathrm{D}$, thereby compromising the effects of vitamin D on suppressing the production of prostate cancer cells [16].

Psychological stress also has been linked to cancer progression, but there is limited evidence for how this impacts cancer promotion [43]. Firefighting and police work involve constant stressors that can potentially affect cancer progression, particularly prolonged stress over years of employment in these jobs [44]. A recent study on stress at work and cancer outcomes found that 
the highest prevalence of stress at work was reported among firemen when compared to other types of occupations [45].

Another factor that may influence our meta-analysis results is prostate cancer screening. Although prostate specific antigen (PSA) testing varies across different countries and within countries, it is believed that protective services workers have frequent and better access to health resources compared to other workers, including access to cancer screening [32]. In North America, for example, firefighters are provided with health information and recommendations on what to consider when completing a health examination with their primary physician, including recommendations for prostate cancer screening [46]. However, it is up to each fire department to disseminate this information and ultimately up to each firefighter to request screening from their primary physician. In this meta-analysis we found slightly lower mortality mREs compared to incidence mREs for firefighters and police officers. As increased screening of prostate cancer leads to the identification of more early stage cases (increased incidence), this may be indicative of a screening effect. However, the mREs for both incidence and mortality were so similar that it was difficult to attribute these differences to screening. Also, prostate cancer screening may not be of high importance in firefighting compared to other cancers (ex. brain, bladder, and colon) and health conditions that have been consistently associated with firefighting. We evaluated study estimates based on different follow-up periods defined as pre-PSA period (prior to 1990 before the PSA test was introduced), during the introduction of PSA testing (early 1990s), and after the introduction of PSA testing (late 1990s and onwards). Although we included studies from different nations, most of the studies were North American so we loosely defined the time periods based on North America. We identified a number of pre-PSA period firefighter studies and observed a meta-risk estimate of 1.26 (95\% CI 0.96-1.67) for these studies. For firefighter studies that had follow-up periods during and after the introduction of PSA testing, we observed a meta-risk estimate of 1.13 (95\% CI 1.02-1.25). It was challenging to define firefighter study follow-up periods as post PSA testing (late 1990s onwards) since most of these studies had follow-up periods that overlapped the early 1990s when PSA testing began. We identified only a few firefighter studies that had later follow-up periods (late 1990s and early 2000s) and observed a meta-risk estimate of 1.58 (95\% CI 1.09-2.29) for these studies. Overall, we observed an elevated risk for firefighter studies that were conducted before the introduction of PSA testing, and a statistically significant elevated risk for firefighter studies that took place during and after the introduction of PSA testing. These findings may be representative of the increased screening that took place over this time period. We attempted to evaluate police studies as well but were limited as almost all included police studies had follow-up periods overlapping periods with and without PSA testing.

Our findings of a slight excess risk of prostate cancer in firefighting and police services should be cautiously interpreted. As expected, there was considerable heterogeneity between studies, particularly in subgroup metaanalyses of police workers and prostate cancer risk that involved small numbers of studies. This makes it challenging to interpret $\mathrm{mRE}$ values with precision [34]. Heterogeneity was likely due to differences in study design and populations studied, follow-up years, occupational exposure assessment and job coding, and adjustment of relative risk values for known or potential covariates. Specifically, there were differences in how the study populations were defined, in terms of paid or unpaid work, full time vs. part time, and eligible employment duration. Some heterogeneity may also be attributed to different follow-up periods in each study, especially those overlapping the pre and post PSA era. The variation in age distribution across included studies could also contribute to heterogeneity based on differences in how studies stratified by age. Some studies had relatively younger populations than other studies and we observed a similar elevated meta-risk estimate for these younger population studies as we did for the overall estimates Publication bias was also considered, but was not recognized as a significant factor as a majority of the included studies were cohort designs. The cohort studies generally looked at multiple cancer sites as outcomes, so it is unlikely that publication bias would have been of concern based on solely prostate cancer results.

A major strength of this meta-analysis is that it was the first to assess prostate cancer risk in both firefighting and police work, replete with subgroup analyses and assessments of study quality, heterogeneity, and publication bias. This meta-analysis captured all previously and newly published studies since the IARC evaluation of firefighting in 2007, and also quantitatively evaluated prostate cancer risk in police studies which had not been done before. Firefighting and police work should be priority areas for investigation because these occupations frequently involve exposure to multiple chemical, biological, physical, and psycho-social hazards. Exposure to some hazards may be associated with increased risk of prostate cancer, although the strength and consistency of associations varies across studies and there are substantial research gaps. Altogether, this research can be used to help identify opportunities for further research on occupation and prostate cancer risk. 
Other occupations of interest with respect to prostate cancer risk are military workers. While we initially sought to include military studies in this meta-analysis, they were ultimately not included because these studies were primarily based on specific historical events (ex. Gulf war) or internal comparisons between military groups [47-62]. This made it difficult to compare findings to other studies that did not focus on single events or that compared workers to the general population. Future assessments can separately consider military studies.

\section{Conclusions}

Overall, the slight excess risks of prostate cancer in firefighting and police services found in this meta-analysis of 31 studies were generally robust to subgroup analyses by outcome (incidence and mortality) and study design. Our findings are important as they show the importance of prostate cancer incidence and mortality among protective services workers, and as this is the first meta-analysis to include both firefighting and police work and prostate cancer risk. The observed findings suggest that screening may not entirely explain our findings, but further investigation into actual screening rates and screening behaviours in firefighting and police work is warranted. Also, further investigations should be designed to assess specific exposures such as benzene, radiation, diesel exhaust, arsenic and cadmium compounds, PAHs, asbestos, and air pollution which are involved in firefighting. Little evidence on how they may relate to prostate cancer risk has been accrued. There is also a need for future studies to examine prostate cancer risk in police work given the small number of police workers published to date. By addressing these important issues in future studies, there will be better understanding on prostate cancer risk in firefighting and police work.

\section{Additional files}

Additional file 1: Table S1. Covariates adjusted for in firefighter and police case-control studies (DOCX $12 \mathrm{~kb}$ )

Additional file 2: Figure S1. Forest plot and mRE of all included cohort studies on firefighters. (DOCX $285 \mathrm{~kb}$ )

Additional file 3: Figure S2. Forest plot and mRE of all included case-control studies on firefighters. (DOCX $137 \mathrm{~kb}$ )

Additional file 4: Figure S3. Forest plot and mRE of all included administrative linkage-based studies on firefighters. (DOCX $153 \mathrm{~kb}$ )

Additional file 5: Figure S4. Forest plot and $\mathrm{mRE}$ of all included cohort studies on police workers. (DOCX $175 \mathrm{~kb}$ )

Additional file 6: Figure S5. Forest plot and $\mathrm{mRE}$ of all included case-control studies on police workers. (DOCX $117 \mathrm{~kb}$ )

\section{Abbreviations}

Cl: Confidence Interval; HR: Hazard Ratio; IARC: International Agency for Research on Cancer; mRE: Meta-risk Estimate; OR: Odds Ratio; PSA: Prostate Specific Antigen; RR: Relative Risk; SIR: Standardized Incidence Ratio; SMR: Standardized Mortality Ratio

\section{Acknowledgements}

We would like to acknowledge Sheila Kalenge's contribution to prostate cancer screening behaviours in firefighters.

Data availability statements

All data generated or analyzed during this study are included in this published article.

\section{Funding}

The corresponding author is supported by the Occupational Cancer Research Centre which is funded by the Canadian Cancer Society, Cancer Care Ontario and the Ontario Ministry of Health and Long-Term Care. Grant number 2014-703257.

\section{Authors' contributions}

The corresponding author, JS, is the main contributor in the design and conceptualization of the study, analysis and interpretation of the data, drafting the work and revising content critically, final approval of the work to be published. MP contributed to the design and conceptualization of the study, analysis and interpretation of the data, drafting and revising the work critically, and final approval of the version to be published. PD contributed to the conceptualizing and design of the study, acquisition and interpretation of the data, drafting the work and revising content critically, and final approval of the work to be published. SH and DC contributed to the design and interpretation of the work, drafting and revising content critically, and final approval of the version to be published. MEP contributed to the design and conceptualization of the study, interpretation of the data, drafting and revising the work critically, and final approval of the version to be published.

Ethics approval and consent to participate

Not Applicable.

\section{Consent for publication}

Not Applicable.

\section{Competing interests}

The authors declare that they have no competing interests.

\section{Publisher's Note}

Springer Nature remains neutral with regard to jurisdictional claims in published maps and institutional affiliations.

\section{Author details}

'Occupational Cancer Research Centre, Cancer Care Ontario, 525 University Avenue, Toronto, ON M5G 2L3, Canada. ${ }^{2}$ Institute of Medical Science, University of Toronto, 525 University Avenue, Toronto, ON M5G 2L3, Canada. ${ }^{3}$ CAREX Canada, Simon Fraser University, Burnaby, Canada. ${ }^{4}$ Dalla Lana School of Public Health, University of Toronto, 525 University Avenue, Toronto, ON M5G 2L3, Canada. ${ }^{5}$ Population Health and Prevention, Cancer Care Ontario, 525 University Avenue, Toronto, ON M5G 2L3, Canada. ${ }^{6}$ INRS-Institut Armand-Frappier, University of Quebec, 531 Boulevard des Prairies, Laval, Quebec H7V 1B7, Canada.

Received: 20 September 2017 Accepted: 27 October 2017 Published online: 17 November 2017

\section{References}

1. International Agency for Research on Cancer. GLOBOCAN 2012: estimated cancer incidence, mortality and prevalence worldwide in 2012. Lyon IARC. 2016. http://globocan.iarc.fr/Pages/fact_sheets_cancer.aspx. Accessed 5 May 2017.

2. Canadian Cancer Society. Prostate cancer statistics. 2015. http://www.cancer. $\mathrm{ca} /$ en/cancer-information/cancer-type/prostate/statistics/?region=on. Accessed 5 May 2017.

3. Dy GW, Gore JL, Forouzanfar MH, Naghavi M, Fitzmaurice C. Global burden of urologic cancers, 1990-2013. Eur Urol. 2017;71:437-336.

4. Plato BA, Concepcion MT. Prostate cancer epidemiology. Arch Esp Urol. 2014;67(5):373-82.

5. Bashir MN. Epidemiology of prostate cancer. Asian Pac J Cancer Prev. 2015; 16:5137-41. 
6. Singh GK, Jemal A. Socioeconomic and racial/ethnic disparities in cancer mortality, incidence, and survival in the United States, 1950-2014: over six decades of changing patterns and widening inequalities. J Environ Public Health. 2017:2819372:1-19.

7. Zuccolo L, Harris R, Gunnell D, Oliver S, Lane JA, Davis M, Donovan J, Neal D, Hamdy F, Beynon R, Savovic J, Martin RM. Height and prostate cancer risk. Cancer Epidemiol Biomark Prev. 2008;17(9):2325-36.

8. Zhao J, Stockwell T, Roemer A, Chikritzhs T. Is alcohol consumption a risk factor for prostate cancer? A systematic review and meta-analysis. BMC Cancer. 2016;16:845.

9. Parikesit D, Mochtar CA, Umbas R, Hamid ARAH. The impact of obesity towards prostate diseases. Prostate Int. 2016;4(1):1-6.

10. Freedland SJ, Aronson WJ. Examining the relationship between obesity and prostate cancer. Rev Urol. 2004;6(2):73-81.

11. Zeegers MPA, Friesema IHM, Goldbohm RA, van den Brandt PA. A prospective study of occupation and prostate cancer risk. J Occup Environ Med. 2004;46(3):271-9.

12. Sauve JF, Lavoue J, Parent ME. Occupation, industry and the risk of prostate cancer: a case-control in Montreal, Canada. Environ Health. 2016;15:100.

13. Parent M-É, Siemiatycki J. Occupation and prostate cancer. Epidemiol Rev. 2001;23(1):138-43.

14. LeMasters GK, Genaidy AM, Succop P, Deddens J, Sobeih T, Barriera-Viruet $H_{\text {, }}$ et al. Cancer risk among firefighters: a review and meta-analysis of 32 studies. J Occup Environ Med. 2006;48(11):1189-201.

15. Wirth M, Vena JE, Smith EK, Bauer SE, Violanti J, Burch J. The epidemiology of cancer among police officers. Am J Ind Med. 2013;56(4):439-53.

16. The International Agency for Research on Cancer. Painting, firefighting, and shiftwork. Lyon; IARC. 2010. http://monographs.iarc.fr/ENG/Monographs/ vol98/mono98.pdf. Accessed 13 Apr 2017

17. Pukkala E, Martinsen Jl, Weiderpass E, Kjaerheim K, Lynge E, Tryggvadottir L, Sparen P, Demers PA. Cancer incidence among firefighters: 45 years of follow-up in five Nordic countries. Occup Environ Med. 2014;71:398-404.

18. Howe GR, Burch JD. Fire fighters and risk of cancer: an assessment and overview of the epidemiologic evidence. Am J Epidemiol. 1990;132: 1039-50.

19. Vena JE, Charles LE, Gu JK, Burchfiel CM, Andrew ME, Fekedulegn D, Violanti JM. Mortality of a police cohort: 1950-2005. J Law Enforc Leadersh Ethics. 2014;1(1):7-20

20. Finkelstein MM. Cancer incidence among Ontario police officers. Am J Ind Med. 1998:34:157-62.

21. Downs, Black. The feasibility of creating a checklist for the assessment of the methodological quality both of randomised and non-randomised studies of health care interventions. J Epidemiol Community Health. 1998; 52:377-284.

22. Higgins JPT, Thompson SG. Quantifying heterogeneity in a meta-analysis. Stat Med. 2002;21:1539-58

23. Bax L, Ikeda N, Fukui N, Yaju Y, Tsuruta H, Moons KGM. More than numbers: the power of graphs in meta-analysis. Am J Epidemiol. 2009;169(2):249-55.

24. Begg CB, Mazumdar M. Operating characteristics of a rank correlation test for publication bias. Biometrics. 1994;50(4):1088-101.

25. Egger M, Smith GD, Scheider M, Minder C. Bias in meta-analysis detected by a simple, graphical test. BMJ. 1997;315:629-34.

26. Ma F, Fleming LE, Lee DJ, Trapido E, Gerace TA, Lai H, Lai S. Mortality in Florida professional firefighters, 1972-1999. Am J Ind Med. 2005;47:509-17.

27. Ma F, Fleming LE, Lee DJ, Trapido E, Gerace TA. Cancer incidence in Florida professional firefighters, 1981 to 1999. J Occup Environ Med. 2006;48(9): 883-8.

28. Demers PA, Checkoway H, Vaughan TL, Weiss NS, Heyer NJ, Rosenstock L. Cancer incidence among firefighters in Seattle and Tacoma, Washington (United States). Cancer Causes Control. 1994;5:129-35.

29. Demers PA, Heyer NJ, Rosenstock L. Mortality among firefighters from three northwestern United States cities. Br J Ind Med. 1992;49:664-70.

30. Daniels RD, Bertke S, Dahm MM, Yiin JH, Kubale TL, Hales TR, Baris D, Zahm $\mathrm{SH}$, Beaumont JJ, Waters KM, Pinkerton LE. Exposure-response relationships for select cancer and non-cancer health outcomes in a cohort of US firefighters from San Francisco, Chicago and Philadephia (1950-2009). Occup Environ Med. 2015;72(10):699-706.

31. Tornling G, Gustavsson P, Hogstedt C. Mortality and cancer incidence in Stockholm fire fighters. Am J Ind Med. 1994;25:219-28.

32. Daniels RD, Kubale TL, Yiin JH, Dahm MM, Hales TR, Baris D, Zahm SH, Beaumont $\mathrm{J}$, Waters KM, Pinkerton LE. Mortality and cancer incidence in a pooled cohort of
US firefighters from San Francisco, Chicago and Philadelphia (1950-2009). Occup Environ Med. 2014;71(6):388-97.

33. Beaumont JJ, Chu GST, Jones JR, Schenker MB, Singleton JA, Plantanida LG, Reiterman M. An epidemiologic study of cancer and other causes of mortality in San Francisco firefighters. Am J Ind Med. 1991;19:357-72.

34. von Hippel PT. The heterogeneity statistic $\mathrm{I}^{2}$ can be biased in small metaanalyses. BMC Med Res Methodol. 2015;15:35.

35. Rao D, Yu H, Bai Y, Zheng X, Xie L. Does night-shift work increase the risk of prostate cancer? A systematic review and meta-analysis. Onco Targets Ther. 2015;8:2817-26.

36. Weichenthal S, Lavigne E, Valois MF, Hatzopoulou M, Van Ryswyk K, Shekarrizfard M, Villeneuve P, Goldberg M, Parent MÉ. Spatial variations in ambient ultrafine particle concentrations and the risk of incident prostate cancer: a case-control study. Environ Res. 2017;156:374-80.

37. Parent MÉ, Goldberg MS, Crouse DL, Ross NA, Chen H, Valois MF, Liautaud A. Traffic-related air pollution and prostate cancer risk in Montreal Canada. Occup Environ Med. 2013:70:511-8.

38. International Agency for Research on Cancer. List of classifications by cancer site with sufficient or limited evidence in humans, volumes 1 to 119. Lyon: IARC. 2017. http://monographs.iarc.fr/ENG/Classification/ Table4.pdf. Accessed 5 July 2017.

39. Flynn-Evans EE, Mucci L, Stevens RG, Lockley SW. Shiftwork and prostate-specific antigen in the National Health and nutrition examination survey. J Natl Cancer Inst. 2013;105(17):1292-7.

40. Parent ME, El-Zein M, Rousseau MC, Pintos J, Siemiatycki J. Night work and the risk of cancer among men. Am J Epidemiol. 2012;176(9):751-9.

41. Papantoniou K, Castano-Vinyals G, Espinosa A, Aragones N, Perez-Gomez B, Burgos J, Gomez-Acebo I, Llorca J, Peiro R, Jimenez-Moleon JJ, Arredondo F, Tardon A, Pollan M, Kogevinas M. Night shift work, chronotype and prostate cancer risk in the MCC-Spain case-control study. Int J Cancer. 2015;137(5):1147-57.

42. Fekedulegn D, Burchfiel CM, Hartley TA, Andrew ME, Charles LE, TinneyZara CA, Violanti JM. Shiftwork and sickness absence among police officers: the BCOPS study. Chronobiol Int. 2013;30(7):930-41.

43. Moreno-Smith M, Lutgendorf SK, Sood AK. Impact of stress on cancer metastasis. Future Oncol. 2010;6(12):1863-81.

44. Violanti JM, Vena JE, Petralia S. Mortality of a police cohort: 1950-1990. Am $J$ Ind Med. 1998;33:366-73.

45. Blanc-Lapierre A, Rousseau MC, Weiss D, El-Zein M, Siemiatycki J, Parent ME. Lifetime report of perceived stress at work and cancer among men: a case-control study in Montreal Canada. Prev Med. 2016;96:28-35.

46. International Association of Firefighters. Annual cancer screening and medical evaluations for firefighters. Ottawa: IAFF. 2017. http://www. iaff1782.org/index.cfm?zone=/unionactive/view_article.cfm\&HomelD= 68377\&page=Health20and20Safety. Accessed 11 July 2017

47. Strand LA, Martinsen II, Borud EK. Cancer incidence and all-cause mortality in a cohort of 21582 Norwegian military peacekeepers deployed to Lebanon during 1978-1998. Cancer Epidemiol. 2017;39:571-7.

48. Yi SW. Cancer incidence in Korean Vietnam veterans during 1992-2003: the Korean veterans health study. J Prev Med Public Health. 2013;46:309-18.

49. Armed Forces Health Surveillance Center. Incidence diagnoses of cancers and cancer-related deaths, active component, U.S. armed forces, 2000-2011. Med Surveillv Mon Rep. 2012;19(6):18-22.

50. Strand LA, Martinsen Jl, Koefoed VF, Sommerfelt-Pettersen J, Grimsrud TK. Cause-specific mortality and cancer incidence among 28300 royal Norwegian navy servicemen followed for more than 50 years. Scand J Work Environ Health. 2011;37(4):307-15.

51. Rogers D, Boyd DD, Fox EE, Cooper S, Goldhagen M, Shen Y, del Junco DJ. Prostate cancer incidence in air force aviators compared with non-aviators. Aviat Space Environ Med. 2011;82(11):1067-70.

52. Cypel $Y$, Kang H. Mortality patterns of army chemical corps veterans who were occupationally exposed to herbicides in Vietnam. Ann Epidemiol. 2010;20(5):339-46

53. Young HA, Maillard JD, Levine PH, Simmens SJ, Mahan CL, Kang HK. Investigating the risk of cancer in 1990-1991 US gulf war veterans with the use of state cancer registry data. Ann Epidemiol. 2010;20(4):265-72.

54. Storm HH, Jorgensen HO, Kejs AMT, Engholm G. Depleted uranium and cancer in Danish Balkan veterans deployed 1992-2001. Eur J Cancer. 2006; 42:2355-8.

55. Yamane GK. Cancer incidence in the U.S. air force: 1989-2002. Aviat Space Environ Med. 2006;77:7789-94. 
56. Akhtar FZ, Garabrant DH, Ketchum NS, Michalek JE. Cancer in the US air force veterans of the Vietnam war. J Occup Environ Med. 2004;46(2):123-36.

57. Silva M, Santana VS, Loomis D. Cancer mortality among service men in the Brazilian navy. Rev Saude Publica. 2000;34(4):373-9.

58. Watanabe KK, Kang HK. Mortality patterns among Vietnam veterans. J Occup Environ Med. 1996;38(3):272-8.

59. Darby SC, Muirhead CR, Doll R, Kendall GM, Thakrar B. Mortality among United Kingdom servicemen who served abroad in the 1950s and 1960s. Br J Ind Med. 1990:47:793-804.

60. Leavy J, Gini A, Lin F. Vietnam military service history and prostate cancer. BMC Public Health. 2006;6:75.

61. Sanderson M, Coker AL, Logan P, Zheng W, Fadden MK. Lifestyle and prostate cancer among older African-American and Caucasian men in South Carolina. Cancer Causes Control. 2004;15:647-55.

62. Giri VN, Cassidy AE, Beebe-Dimmer J, Smith DC, Bock CH, Cooney KA Association between agent orange and prostate cancer: a pilot casecontrol study. Urology. 2004;63:757-61.

63. Glass DC, Pircher S, Del Monaco A, Vander Hoorn S, Sim MR. Mortality and cancer incidence in a cohort of male paid Australian firefighters. Occup Environ Med. 2016;73:761-71.

64. Brice A, Jean-LuC M, Frederic M, Stephane D, Gaelle C, Simone MP, Christian L, Ellen I, Patrick B. French firefighter mortality: analysis over a 30-year period. Am J Ind Med. 2015;58:437-43.

65. Ahn YS, Jeong KS, Kim KS. Cancer morbidity of professional emergency responders in Korea. Am J Ind Med. 2012;55:768-78.

66. Baris D, Garrity TJ, Telles JL, Heineman EF, Olshan A, Zahm SH. Cohort mortality study of Philadelphia firefighters. Am J Ind Med. 2001;39:463-76.

67. Bates MN, Fawcett J, Garrett N, Arnold R, Pearce N, Woodward A. Is testicular cancer an occupational disease of fire fighters? Am J Ind Med. 2001;40:263-70

68. Aronson KJ, Tomlinson GA, Smith L. Mortality among fire fighters in metropolitan Toronto. Am J Ind Med. 1994;26:89-101.

69. Giles G, Staples M, Berry J. Cancer incidence in Melbourne metropolitan fire brigade members, 1980-1989. Health Rep Stat Can. 1993;5(1):1-38.

70. Guidotti TL. Mortality of urban firefighters in Alberta, 1927-1987. Am J Ind Med. 1993;23:921-40

71. Grimes G, Hirsch D, Borgeson D. Risk of death among Honolulu fire fighters. Hawaii Med J. 1991;50(3):82-5.

72. Vena JE, Fiedler RC. Mortality of a municipal-worker cohort: IV. Fire fighters. Am J Ind Med. 1987;11:671-84.

73. Tsai RJ, Luckhaupt SE, Schumacher P, Cress RD, Deapen DM, Calvert GM Risk of cancer among firefighters in California, 1988-2007. Am J Ind Med. 2015;58(7):715-29.

74. Kang D, Davis LK, Hunt $P$, Kreibel D. Cancer incidence among male Massachusetts firefighters, 1987-2003. Am J Ind Med. 2008;51:329-35.

75. Krstev S, Baris D, Stewart P, Dosemeci M, Swanson GM, Greenberg RS, Schoenberg JB, Schwartz AG, Liff JM, Hayes RB. Occupational risk factors and prostate cancer in U.S. blacks and whites. Am J Ind Med. 1998;34:421-30

76. Gu JK, Charles LE, Burchfiel CM, Andrew ME, Violanti JM. Cancer incidence among police officers in a U.S. northeast region: 1976-2006. Int J Emerg Mental Health. 2011;13(4):279-89.

77. Forastiere F, Perucci CA, Di Pietro A, Miceli M, Rapiti E, Bargagli A, Borgia P. Mortality among urban policemen in Rome. Am J Ind Med. 1994;26:785-98.

78. Bouchardy C, Schuler G, Minder C, Hotz P, Bousquet A, Levi F, Fisch T, Torhorst J, Raymond L. Cancer risk by occupation and socioeconomic group among men - a study by the association of swiss cancer registries. Scand J Work Environ Health. 2002;28 suppl(1):1-88.

79. Sritharan J, Demers PA, Harris SA, Cole DC, Peters CE, the Canadian Cancer Registries Epidemiology Research Group, Villeneuve PJ. Occupation and risk of prostate cancer in Canadian men: a case-control study across eight Canadian provinces. Cancer Epidemiol. 2017a;48:96-103.

80. Sritharan J, Demers PA, Harris SA, Cole DC, Kreiger N, Sass-Korstak A, Lightfoot N. Natural resource-based industries and prostate cancer risk in northeastern Ontario: a case-control study. Occup Environ Med. 2016;73: 506-11.

\section{Submit your next manuscript to BioMed Central and we will help you at every step:}

- We accept pre-submission inquiries

- Our selector tool helps you to find the most relevant journal

- We provide round the clock customer support

- Convenient online submission

- Thorough peer review

- Inclusion in PubMed and all major indexing services

- Maximum visibility for your research

Submit your manuscript at www.biomedcentral.com/submit

) Biomed Central 